\title{
OBITUARY
}

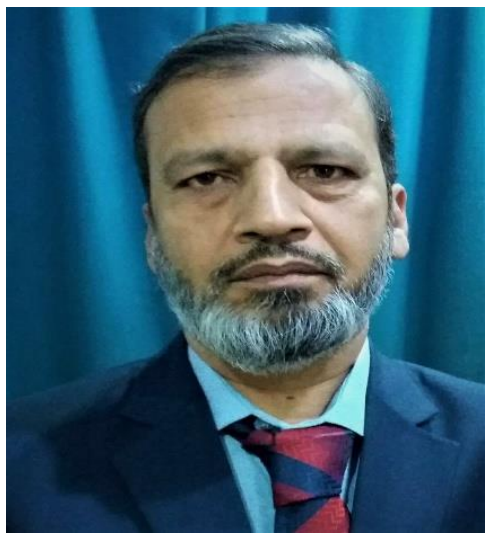

\section{Hafiz Maqsood Ali, DA, FCPS}

COVID-19 snatched a genius, pious and a down-to-earth humble man and a highly intelligent and professionally competent Anesthesiologist from us on 4 June 2020; Hafiz Maqsood Ali was a person, who cannot be described in words. He had always been the heart and soul of anesthesia team, wherever he happened to serve.

He was born on 15 July 1964 to a modest family at Lahore. He obtained his elementary education at Dar-ul-Uloom Islamia, Tajpura Road, Lahore, and to the pride of his parents became a hafiz of Holy Quran, when he was just eleven years old. For conventional schooling he was admitted to Islamia High School Lahore Cantt, and then he secured a merit seat in Punjab Medical College, Faisalabad for medical graduation.

For post-graduate qualification in anesthesiology he chose Services Institute of Medical Sciences (SIMS), Lahore. He served as consultant anesthesiologist at prime hospitals of his native city including General Hospital, Mayo Hospital, and Services Hospital, Lahore. Services Hospital was his last institution as associate professor.

Dr. Hafiz Maqsood Ali joined our department at Services Hospital, Lahore, as Medical officer. He never cared for his duty hours, and could work continuously round the clock if such a need arose. He was always seen reading verses of Holy Quran, whenever he found some free time. His senior and junior colleagues often benefited from his teachings from Holy Quran and Hadith.

He was a great trainer, and had a motto to 'train the trainers'. He was one of the elite supervisors and examiners of Anesthesiology faculty of College of Physicians \& Surgeons Pakistan (CPSP). Anesthesiologists trained by him are working all over the country as well as in many other countries of the world.

He ultimately sacrificed his life while taking care of COVID-19 patients. Let us pray for him that Allah Almighty bless him with the highest place in Jannah. We will always remember in our hearts!

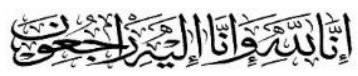

\section{Akmal Khan}

Registrar, Anesthesia Department,

Services Hospital, Jail Road, Lahore, Pakistan. 